\title{
Havana Tradition Platform Pipe Production and Disposition: Implications for Interpreting Regional Variation in Midwestern Hopewell Ceremonialism
}

\author{
Kenneth B. Farnsworth, Thomas E. Emerson (D), and Randall E. Hughes
}

\begin{abstract}
This study documents the contexts of platform pipe creation, distribution, and disposition at Illinois Havana Hopewell Tradition (50 $B C$ to $A D$ 200-250) sites to identify regional variation in Hopewell ceremonialism and exchange. We observe that the large deposits of stone pipes buried during communal rituals in the Scioto Valley and the continued influence of the Hopewell Sphere of Interaction have skewed archaeological interpretation. Aside from the several large deposits, pipes are limited in the Scioto Tradition and seldom found in habitation areas. In Illinois, pipe fabrication debris commonly occurs in habitation areas along with numerous examples of pipe repair and maintenance. Local pipestones—often from northern Illinois Sterling deposits—predominate, and exotic imported pipestones are unusual. Pipes are rare inclusions with individual burials as indicators of status, spiritual prowess, achievement, or group membership. The high value placed on pipes as communal sacra in Ohio and their value in Illinois as items of personal influence parallels their common occurrence in Illinois and their unique context in Ohio Hopewell. This study of the contexts of pipe manufacture and deposition reinforces current discussions of such artifact assemblages as important in documenting local variations in political, social, and religious mortuary ceremonialism across the "Hopewellian sphere."
\end{abstract}

Keywords: Hopewell ceremonialism, platform pipes, Havana Tradition, pipestone sourcing, Hopewell localization

Este estudio documenta el contexto de la creación, distribución y disposición final de tuberías de plataforma en los sitios arqueológicos de la Tradición Hopewell de La Habana de Illinois (50 a C a 200-250 dC) como un paso para revelar la variación regional en el ceremonialismo, el intercambio y la artesanía de Hopewell. Observamos que los depósitos inusualmente grandes de pipas de piedra exóticas enterradas durante los rituales comunales en el Valle de Scioto y la influencia continua de la Esfera de Interacción de Hopewell han sesgado las interpretaciones arqueológicas de estos objetos. Aparte de los varios depósitos grandes, estas tuberías son limitadas en Ohio y rara vez se encuentran en las áreas de habitación de la Tradición Scioto. En Illinois, los escombros y fragmentos de la fabricación de tuberías ocurren comúnmente en áreas habitadas junto con numerosos ejemplos de reparación y mantenimiento de tuberías. Predominan las piedras para tuberías locales, a menudo de depósitos de piedra para tuberías Sterling del norte de Illinois, y las piedras para tuberías importadas exóticas son inusuales. Las pipas son inclusiones raras con entierros individuales, presumiblemente como indicadores de estatus, destreza espiritual, logros o pertenencia a un grupo. El alto valor otorgado a las pipas como sacra común en Ohio y su valor en Illinois como elementos de influencia personal es paralelo a su ocurrencia común en Illinois y su contexto más singular en Ohio Hopewell. Este estudio del contexto de la fabricación y deposición de pipas refuerza las discusiones actuales de tales ensamblajes de artefactos como importantes para documentar las variaciones locales en el ceremonialismo mortuorio político, social y religioso a través de la "esfera Hopewelliana".

Palabras clave: ceremonialismo Hopewell, tuberías de plataforma, tradición de La Habana, abastecimiento de pipestone, localización Hopewell

Kenneth B. Farnsworth and Thomas E. Emerson (kfarnswo@illinois.edu; teee@illinois.edu, corresponding author) Illinois State Archaeological Survey, 23 East Stadium Drive, University of Illinois, Urbana-Champaign, IL 61820, USA Randall E. Hughes (randall.hughes@ hotmail.com) — Illinois State Geological Survey, Natural Resources Building, 615 East Peabody Drive, University of Illinois, Urbana-Champaign, IL 61820, USA

American Antiquity 86(4), 2021, pp. 696-714

Copyright (C) The Author(s), 2021. Published by Cambridge University Press on behalf of the Society for American Archaeology. This is an Open Access article, distributed under the terms of the Creative Commons Attribution-

NonCommercial-ShareAlike licence (http://creativecommons.org/licenses/by-nc-sa/4.0/), which permits non-commercial re-use, distribution, and reproduction in any medium, provided the same Creative Commons licence is included and the original work is properly cited. The written permission of Cambridge University Press must be obtained for commercial re-use. doi:10.1017/aaq.2021.34 
$\mathrm{F}$ Irom the onset of antiquarian endeavors in America, practitioners, lacking chronological and often contextual controls, sought to define patterned human behavior manifested within the material assemblages, mortuary remains, and monumental constructions they encountered. The nineteenth-century EuroAmerican observation of the expansive Ohio earthworks, with their artistic and exotic contents, and the recognition that similar artifacts and patterns of behavior seemed to be spread across the eastern United States challenged interpretation on many fronts (e.g., Abrams 2009; Byers 2015; Carr 2005a:576-577; Squier and Davis 1848). Some interpreters, steeped in concepts of progressive culture change and employing a "direct historical approach," failed to link the Native people with their history and promulgated the so-called Moundbuilder myth (e.g., Byers 2015:12-15; Silverberg 1968).

Subsequent investigators understood the Hopewell phenomena as a development of Native societies, but they often continued to treat the observed material culture and implicit behavior as generated by a single interregional cultural system (see discussions in Applegate 2005; Byers 2015; Carr 2005b; Carr and Case 2005; Henry and Miller 2020). From such foundations emerged Joseph Caldwell's (1964) widely known Hopewell Interaction Sphere (HIS), consisting of a widespread series of regional traditions that shared iconographic, religious, and mortuary practices and behaviors.

Although widely discarded, we observe that there continues to be an innate tendency in some studies to incorporate earlier Ohio-centric and HIS perspectives into interpretations of regional Hopewell ceremonialism and interaction. As researchers tack between the local and the universal, they often create a continuing challenge to understanding Hopewell by persisting in seeking the transformation of local events through universal explanations. We conclude (as have others before us) that interpreting the Havana Tradition predominantly within the context of a Hopewellian Ohio-centric interaction sphere has hindered our understanding of its unique local social, religious, and political development, which occurs quite outside the Ohio Hopewell sphere of influence.

\section{Recognizing Variance}

Many researchers in the last few decades have rejected monolithic models of universal interregional causation that were embedded in the HIS as they increasingly explored the crucial nature of local and intraregional Middle Woodland ceremonial interactions and variation (e.g., Carr and Case, ed. 2005; Case and Carr, ed. 2008; Charles and Buikstra, eds. 2006; Henry and Miller 2020; Redmond et al. 2019, 2020; Seeman 2020; Wright 2020; but see Byers $2015^{1}$ ). They emphasize the innovative power of people's actions within their local sociocultural context and often employ post-processual metaphors involving concepts of bundling, assemblages, and situations as descriptors (e.g., Henry and Miller 2020), and they conceptualize the regional and local effects of Hopewell through models of hybridity, creolization, or glocalization (e.g., Wright 2020). Rather than emphasizing an interregional landscape, scholars have deconstructed the HIS into (a) its expressions in raw materials, artifact styles, and mortuary, religious, and cultural practices; (b) its unique geographic manifestations; and (c) the cultural mechanisms that enacted the movement of objects (after Carr 2005a:575-623). It is now understood that, in fact, there are many instances of localized Hopewell ceremonialism, each sharing some broader Hopewellian aspects, but each also locally unique with its own developmental history.

Integral to these efforts has been the swing of archaeological concern from discerning broad cultural patterns to the recognition of the importance of local variance. This shift paralleled the demise of the HIS and moves the focus to investigating expressions of localized Hopewell-era events across the Eastern Woodlands. This shift has produced a wide array of new theoretical insights, which variously distinguish perspectives characterized in idioms such as events, bundles, entanglements, assemblages, or situations. Although semantically contrasted by their proponents, all of these variants seek to perceive the multiscalar effects of human actions, materials, and otherworldly beings as expressed in materials at the microscale. Assemblages - a concept with multiple, deep roots in archaeology-are reconceived to emphasize their transitory and 
fluid contents as well as their potential for creating multiple outcomes. Assemblages and the situations in which they are manifest seem particularly applicable for examining the wide-ranging variations and impacts of Hopewell ceremonialism (e.g., see Henry and Miller, ed. 2020). Perhaps these concepts are most succinctly summarized by Henry and Miller (2020:197), who regard "Middle Woodland situations as a way to conceive of, and explore, the material manifestations of institutional interactions reflecting different assemblages of actors, ideas, and experiences at various times and places." Although only briefly touching on this in this article, we suggest that, conceptually, assemblages and situations provide an interesting and fruitful way forward in examining the apparent different implications and effects of platform pipes in Illinois versus Ohio ceremonialism. Consequently, in this discussion, we detail the local (Illinois Havana) "situation" - to the general exclusion of interregional patterns, interpretations, or comparisons - through the observable contextual assemblage variance employed by Illinois Havana Hopewell people in the manufacture, use, and deposition of platform pipes.

\section{Hopewell Platform Pipe Research}

To illustrate this approach, we have assembled the baseline data related to the manufacture, raw materials, distribution, contexts, and utilization of platform pipes during the Hopewell expression of the local Illinois Havana Tradition (e.g., Farnsworth et al. 2013). To perform this research, we depended primarily on objects from legacy collections curated by historical societies, museums, and universities. These pipes have a documentary trail, and they were recovered during institutionally sponsored excavations. In a few instances (less than 5\%), we included pipes recovered by landowners during agricultural or mound-leveling activities for which we had secure documentation of context. The insistence on historical documentary evidence is essential to such research given that Hopewell pipes are highly valued and have a long history of being forged, and that many of these forgeries have been accessioned into institutional collections. Additionally, in this published research, we have avoided identifying individual pipes, except those that we have illustrated that were already well known in the literature. (For a detailed discussion of the challenges of working with legacy collections, see Supplemental Text 1.)

This study of Hopewell pipes is an integral aspect of our broader long-term geologic sourcing research investigating Native use of midcontinental pipestone quarries to identify the sources of Hopewellian stone platform pipes from sites in the Great Lakes Riverine area (e.g., Supplemental Text 2; Emerson et al. 2005, 2013, 2021; Hughes et al. 1998; Wisseman et al. 2012; Figure 1). We seek to (a) identify the mineralogical signatures of the raw materials used, (b) tie those to geological source areas to examine Woodland regional Native interaction around 200 BC-AD 400 (c) record details of prehistoric pipe manufacturing, and (d) gather data on variation in pipe styles and context both regionally and over time.

\section{Havana Hopewell}

By the mid-twentieth century, regional researchers had recognized the presence of a distinct Middle Woodland burial and cultural complex in western Illinois that they labeled the Havana Tradition (Asch et al. 1979; Deuel 1952; Griffin 1967; Struever 1964, 1968). In this study, we concentrate on the spatial and chronological core of the Havana Hopewell Tradition in the central (Fulton-Ogden phase) and lower (Mound House phase) Illinois River valley and the adjacent American Bottom (Holding phase; Asch et al. 1979; Charles and Buikstra 2002; Charles et al. 1988; Farnsworth 2004; Farnsworth and Asch 1986; Fortier 2006; Fortier et al. 1989; Griffin 1967; Ruby et al. 2005) between cal 50 BC and cal AD 200-250, marking the Tradition's most significant Hopewell expression. Geographically, we concentrate on a nearly continuous $430 \mathrm{~km}$ linear strip of river bottom and bluff topography from the Great Bend of the Illinois River to its junction with the Mississippi River at the northern end of the American Bottom at Alton, Illinois, and then south along its western shore to the Monroe County line. We also examine important Hopewell site clusters in the Quad Cities, Illinois, area and in Iowa across from the Mississippi-Rock River confluence. These landscapes are rich in bottomland riverine environments, backwater lakes, and swamps with 


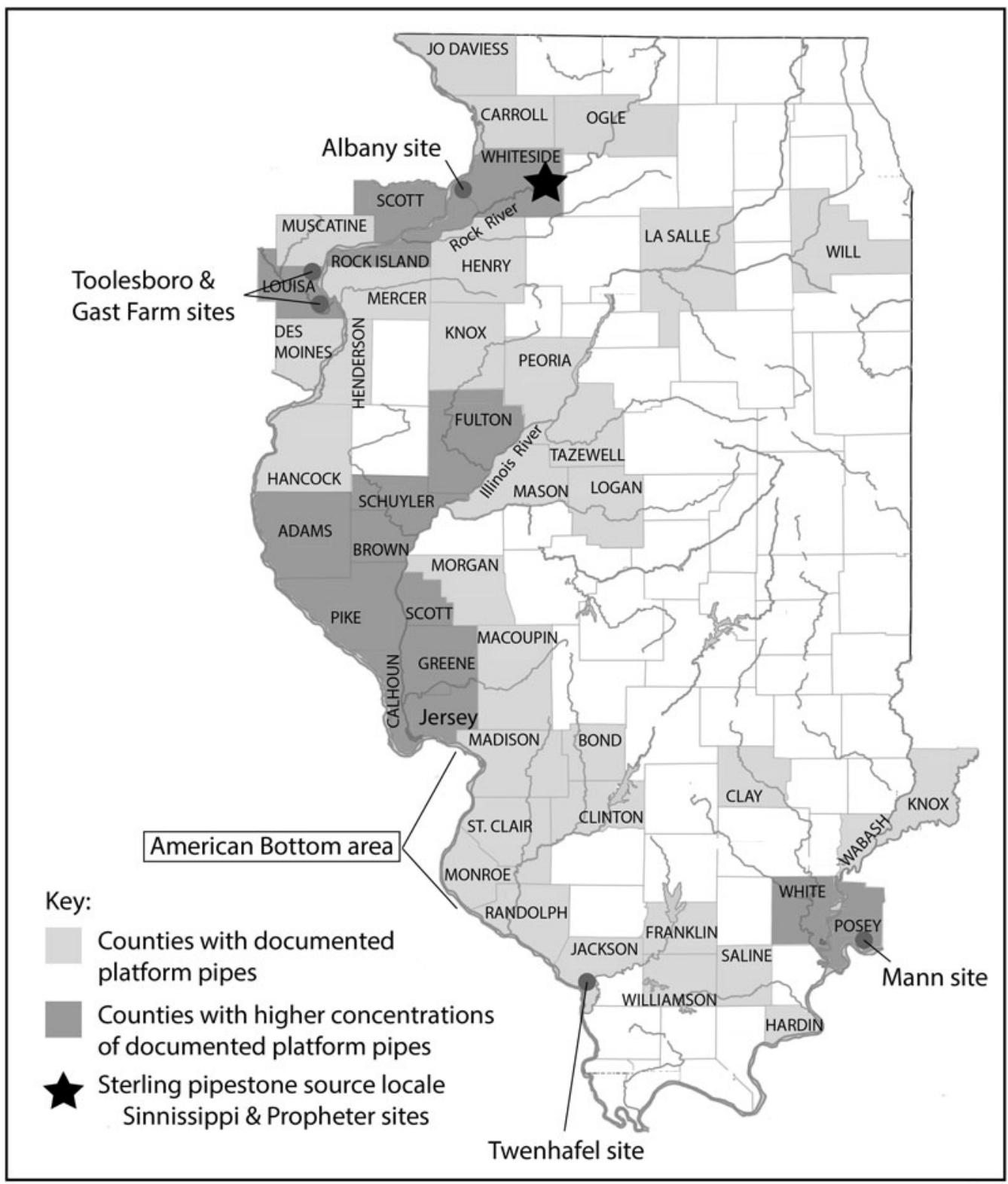

Figure 1. Illinois regional platform-pipe distributions by county, high-density areas of documented pipes from habitation and mortuary sites, archaeological sites and locales highlighted in the text, and the Sterling pipestone source area (map courtesy of Kjersti Emerson).

abundant aquatic, mammalian, and waterfowl resources as well as fertile fields for Early Agricultural Complex farmers, hunters, and gatherers.

\section{Havana Hopewell Platform Pipes}

Smoking pipes are one of the emblematic markers of the Hopewell phenomena. Since their first antiquarian discovery in 1846 in a large deposit at the Mound City site near Chillicothe, Ohio (Squier and Davis 1848; also Mills 1922), and later at Tremper Mound near the mouth of the Scioto River (Mills 1916), these small, artistically crafted objects have been central to scholars' interpretations of Ohio Hopewell's 
dominating position in the HIS (e.g., Seeman 1977, 1979; Struever and Houart 1972). Most Hopewell pipes were presumed to have been manufactured from local Feurt Hill Ohio pipestone deposits adjacent to Tremper Mound for distribution and exchange across the HIS (e.g., Mills 1916). Our geologic sourcing of the pipestone used in pipes in the Ohio heartland, however, demonstrated that the pipes in such Early Hopewell deposits as Tremper Mound were dominated by Sterling pipestone from northern Illinois, catlinite from the Minnesota quarries, and local Ohio claystone and limestone, with only a small percentage $(\sim 6 \%)$ of the pipes made from Feurt Hill pipestone (Emerson et al. 2005, 2013). Later Mound City Ohio pipe deposits were dominated by local pipestones, and exotic Illinois and Minnesota pipestones were absent (Emerson et al. 2013). Having demonstrated that early Ohio Hopewell people's focus included the importation of nonlocal pipes from western quarries, we expanded our research to examine pipestone sources employed in pipe manufacture in the other proposed center of Hopewell interaction-the Havana Hopewell Tradition centered on the Illinois River valley (Farnsworth et al. 2004, 2013; Hughes et al. 1998; Supplemental Text 2).

\section{Havana Tradition Pipe Development}

We have published a detailed analysis of initial Havana and terminal Havana Tradition pipe manufacture and context in Illinois (Farnsworth et al. 2016; Koldehoff and Farnsworth 2018). The precursors of classic Havana Hopewell-era platform pipes ( $250 \mathrm{BC}$ to AD 200-250) can be shown to have emerged from Late Archaic / Early Woodland tube pipes that were modified into transitional split-stem tube forms at the Early Woodland to Middle Woodland boundary (cal 250-150 BC; Koldehoff and Farnsworth 2018:Figure 1.7; Figure 2). The Initial Havana Tradition Middle Woodland (cal 200-50 BC) pipes continue the split-base form, but the bases are now flattened into a broader V-base with a plain bowl (with rare examples of effigy bowls; Koldehoff and Farnsworth 2018: Figure 1.9). This form is generally confined to Illinois, and it has been most often recovered from mortuary contexts. It is at this point that

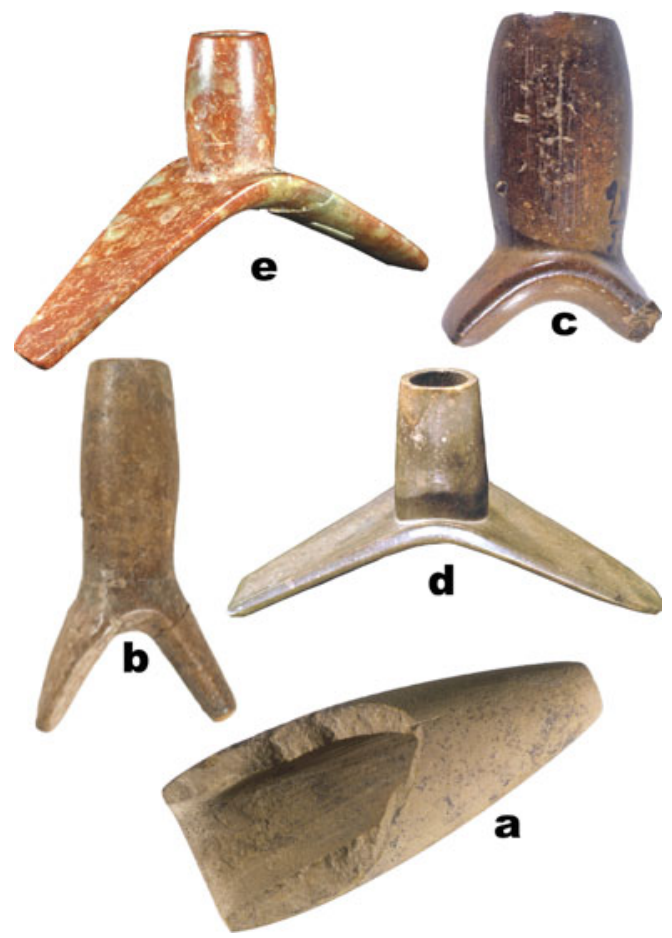

Figure 2. Illinois platform-pipe styles presented by chronological position: (a) Archaic-Early Woodland tube pipes ( 1500-600 BC); (b-c) Sister Creek Split stem pipes ( 500-200 BC); (d-e) Ogden-Fettie V-base pipes ( 200-50 BC) (not to scale; photographs courtesy of Kenneth Farnsworth). (Color online)

Illinois Sterling pipestone becomes a prominent material employed in pipe manufacture.

The classic Havana Hopewell plain and effigy platform-pipe forms that are the subject of this article emerge about cal $50 \mathrm{BC}$ and continue to cal AD 250-300 (see examples, Figure 3). Post-Havana Hopewell platform-pipe manufacture continued using Sterling pipestone into the Late Woodland period (cal AD 500-700), although in decreasing amounts (Figure 4). Farnsworth and colleagues (2016:Figures 1, 5, and 6) identified several terminal and post-Havana Hopewell pipe styles in Illinois. These include the Hopewell-17 style (Seeman 1977) pipes dating from the end of the Havana Hopewell era to the early Late Woodland transition at about cal AD 300-400. The subsequent early Late Woodland Weaver phase sees a shift to flared bowl, flat-based "Cinnamon" style pipes, along with a possible companion variant "Baraboo" style and 

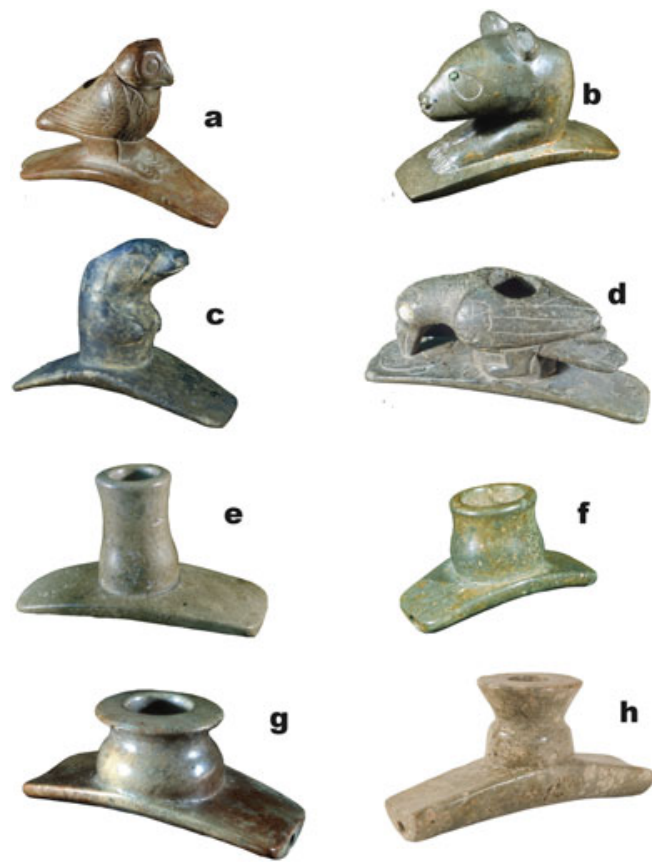

Figure 3. Examples of Sterling pipestone animal-effigy and plain-bowl platform-pipe styles excavated from Illinois Havana Hopewell mortuary sites: (a) Mississippi Valley owl-effigy pipe from Ansell-Knight Mound \#4, Calhoun Co.; (b) Wabash Valley bear-effigy pipe from Wilson Mound \#6, White Co.; (c) otter-effigy pipe from Wilson Mound \#6, White Co.; (d) Illinois Valley raven-effigy pipe from Gibson Mound \#4, Calhoun Co.; (e) Mississippi Valley plain-bowl pipe from Albany Mound \#20, Whiteside Co.; (f) Illinois Valley plain-bowl pipe from Naples-Abbott "Ballard" Mound, Scott Co.; (g) Illinois Valley plain-bowl pipe from Bedford Mound \#12, Pike Co.; (h) Illinois Valley plain-bowl pipe from the Oscar Hood Mound, Schuyler Co. (not to scale; photographs courtesy of Kenneth Farnsworth). (Color online)

a shouldered "Nutwood" style form. The distribution, contexts, and dating of these later Woodland pipe styles is incompletely understood. Farnsworth et alia (2016), however, remark on the significant decrease in the use of Sterling pipestone for pipe manufacture in the Late Woodland period.

\section{Middle Woodland Use of Sterling Pipestone}

The principal Sterling pipestone exploitation area on the lower Rock River has a long history of pipestone artifact manufacture and use that dates from the Middle Archaic to the historic period (Farnsworth 2020; Farnsworth and Hedman

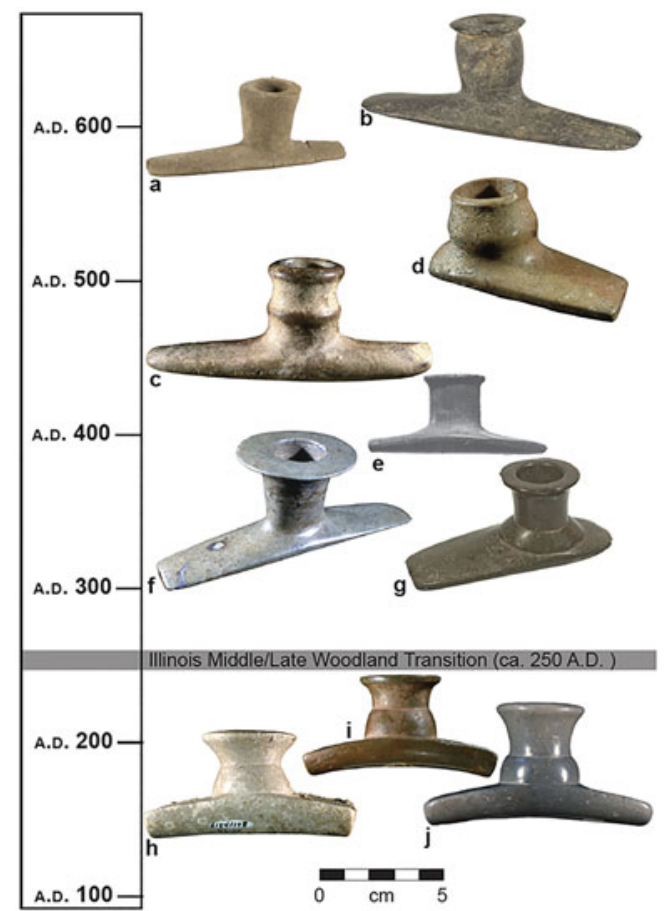

Figure 4. Illinois platform-pipe styles presented by chronological position: Hopewell and Post-Hopewell pipes; Elizabeth Mound Style (a-b), Brown County Bowl style (c-d), aka Nutwood style; Ray Md. Style (e) Clear Lake (f) and Prairie du Rocher (g), aka "Cinnamon" style; Gibbon, aka "Monitor" or "Hopewell Md. 17" styles (h-j) (Courtesy of the Illinois State Archaeological Survey; photographs courtesy of Kenneth Farnsworth). (Color online)

2020; Farnsworth et al. 2004:186-189, 2016; Hughes et al. 1998). Only during Middle Woodland times, however, does this local industry expand beyond the northwestern Illinois area to include most of Illinois and parts of Iowa, Indiana, and Ohio. Our research and that of colleagues have documented intense Middle Woodland Sterling pipestone exploitation for artifact manufacture in the Sterling source area and along the lower Rock River drainage (Farnsworth 2020; Farnsworth et al. 2004:186-189). Hundreds of Sterling pipestone cobbles, chunks, and flakes of manufacturing debris in excavations and local private collections have been documented from the Middle Woodland Propheter and Gast Farms habitations, as well as the Sinnissippi, Albany, and Toolesboro mound sites. Additionally, 14 platform-pipe preforms 


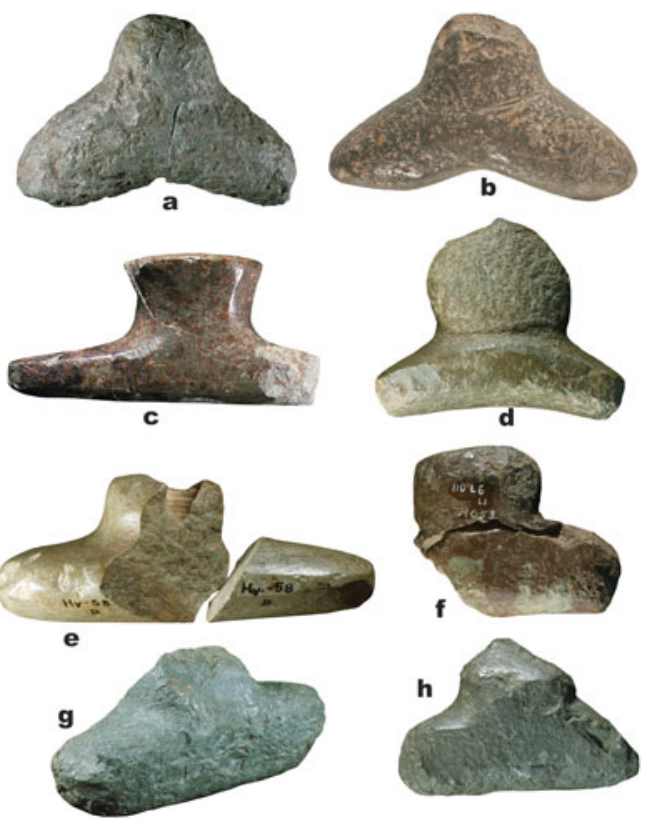

Figure 5. Examples of Sterling pipestone platform-pipe preforms recovered from Illinois Middle Woodland habitation sites: (a) Illinois Valley Ogden-Fettie site, Fulton Co.; (b) Rock River Valley Sterling area (vicinity of Propheter site) private-collection preform, Whiteside Co.; (c, d, h) Rock River Bluff workshop, E. Moline, Rock Island Co.; (e) Rock River Valley Hokinson site, Henry Co.; (f) Mississippi Valley Albany site south habitation area, Whiteside Co.; and (g) Mississippi Valley preform from Sconce-Shudel site, Calhoun Co. (not to scale; photographs courtesy of Kenneth Farnsworth). (Color online)

of Sterling pipestone have been collected at Middle Woodland sites, primarily clustered in the source locales in the central Rock River Valley, in the Albany earthwork center, and in Louisa County, Iowa (Figures 1 and 5). An additional eight preforms of local stones, indicating a wider scope of raw material used in pipe manufacturing, have also been identified. Most of these occur in habitation sites, but two were found with burials.

These studies-along with largely unpublished survey and excavation research by William Green, Shannon Fie, Tom Wolforth, Jim Anderson, Rochelle Lurie, and Gene Gray-have documented Native Sterling pipestone exploitation in the source area and along the lower Rock River drainage. For instance, investigations at the Middle Woodland Propheter site, near the confluence of Elkhorn Creek and the Rock River, recovered
141 pieces of early stage Sterling pipestone manufacturing debris as well as a preform fragment and part of a pipe bowl (Farnsworth 2020; Farnsworth et al. 2004).

A significant Havana Hopewell mound and village site is located on the bluffs and floodplain of the Rock River on the southeast edge of Sterling, Illinois. The Sinnissippi site contained approximately 20 mounds and a possible earthwork that were explored in a number of antiquarian excavations. In the 1930s, the site was recorded by the nascent University of Chicago Anthropology program, and later test excavations were conducted in the habitation area by Elaine Bluhm, Illinois Archaeological Survey (Bluhm et al. 1961, summarized in Farnsworth 2020). No pipes or preforms were reported from the mounds or the habitation areas. Avocational collecting activities at the Sinnissippi site and adjacent areas, however, produced numerous pipestone artifact fragments and unmodified chunks and cobbles of quarried Sterling pipestone raw material (Farnsworth 2020).

Additionally, we have studied an excavated private collection from a habitation area adjacent to the Albany mounds site, a sprawling Middle Woodland ritual center that includes more than 80 burial mounds, located in the Mississippi Valley about $50 \mathrm{~km}$ upstream from the Rock RiverMississippi confluence and $45 \mathrm{~km}$ directly overland west of the Sterling area (Figure 1). These collections included several fragmentary pipestone artifacts and a substantial assemblage of chunks and flakes of pipestone manufacturing debris. Bluhm Herold (1971) assembled and evaluated the information from extensive antiquarian investigations of two dozen mounds at Albany by members of the Davenport Academy and Museum. Most notable is the absence of Hopewell ritual artifacts. Only a single plain platform pipe was found in a mortuary context, despite the presence of Sterling pipestone debris and pipe fragments in the village midden (Bluhm Herold 1971; Farnsworth et al. 2004). This pattern of few grave inclusions closely resembles that at the Sinnissippi site.

Across the Mississippi River, however, is a cluster of Havana Tradition sites located in Louisa County, Iowa, just $34 \mathrm{~km}$ south of the mouth of the Rock River, with substantial evidence of 
pipe manufacturing. These sites include the impressive Hopewell-era Toolesboro complex (Alex et al. 2019) and the nearby Gast Farm site (Green 2018; Whittaker and Green 2010). Nineteenth-century antiquarian excavations at Toolesboro recorded at least 20 mounds and a geometric earthwork. These mounds yielded a moderate array of typical Hopewell-era artifacts, including obsidian, various copper forms, mica, pearls, marine shell cups and beads, ceramics, and lithics. Significantly, at least eight platform pipes were recovered, including both effigy (birds and mammals) and plain-bowl forms (Hopewell-17 style), as well as a limestone pipe preform (Alex et al. 2019:51-53, 58 and Figures 35-45, 66). Because lithic debris was not collected in these early investigations, it is not possible to determine if, or at what level, pipe manufacture was performed.

By contrast, there is ample evidence of manufacturing employing Sterling pipestone at the nearby Gast Farm site. Modern excavations at the Havana Hopewell-era habitation component found that it contains abundant pipestone debitage as well as preforms and unfinished and broken pipes (William Green, personal communication 2020). Ongoing analysis by Shannon Fie (personal communication 2020) revealed over 600 Sterling pipestone fragments, including three finished plain-bowl pipes, a plain-bowl pipe preform, and multiple pieces of worked/drilled pipestone. The assemblage comes from a small sample of excavated features and from surface collections, which led the excavator, William Green (personal communication 2020), to estimate that there may be thousands of Sterling pipestone fragments on the site.

The evidence for the collection of Sterling pipestone as well as the crafting of Sterling pipestone pipes in the lower Rock River and adjacent mound/earthwork sites along the Mississippi River valley (Albany-Gast Farm-Toolesboro) is substantive in terms of Sterling pipestone chipping debris, worked fragments, preforms, and broken pipes. Moreover, the Illinois Havana Hopewell habitation sites show that finished pipes are treasured and curated by those who possess them, as evidenced by pipe wear, repair, and modification for continued use when damaged (Figure 6). Given the widespread presence of pipe-making debris, however, there is no clear evidence at Illinois Middle Woodland sites for the practice of restricted ritualized or specialized crafting (sensu Everhard and Ruby 2020). At the same time, we recognize that pipes manufactured of Sterling pipestone are present in the early Tremper Mound caches in Ohio (Emerson et al. 2013). ${ }^{2}$ The mechanism employed to facilitate this movement of a significant number of pipes from Illinois to Ohio is unclear. The widespread occurrence of pipestone debris in Illinois sites indicates that many residents had access to the raw materials, although the artistic uniformity of some pipes suggests that only a few craftspeople carved many of the high-quality pipes. A detailed study linking raw materials to stylistic variation is clearly warranted.

\section{Pipe Distribution and Contexts}

In our Illinois regional study area-which includes all 102 Illinois counties, four eastern Iowa counties (Scott, Louisa, Muscatine, Des Moines), and two southwestern Indiana counties (Posey, Knox)-we documented 423 complete and fragmentary platform pipes and pipe preforms from 200 discrete archaeological sites (185 sites in Illinois, 11 in Iowa, and four in Indiana) with reasonably secure historical and/or archaeological context. ${ }^{3}$ Examining the history of Illinois-area platform pipe use during the entire range of the Middle Woodland reveals patterns that provide insight into the role of the pipes among the area's populations. The depositional contexts of intact and fragmentary pipes are evenly distributed between 96 habitation middens (49\%) and 104 earthwork mortuaries (52\%) but, numerically, slightly more intact specimens $(n=195$, $64 \%$ ) are recovered from a mortuary setting (Table 1). Effigy pipes represent only about $22 \%$ (66 of 305) of all intact pipes documented and, as might be expected, most effigies ( $n=49$ of 66 total, $74 \%$ ) were recovered from a mortuary context. A total of 21 ceramic pipes (four effigy and 17 plain-bowl pipes) are omitted from this study. Eleven were from mortuary contexts.

\section{Raw Materials in Pipes}

In this discussion, we concentrate on the 169 Havana Hopewell-era pipes (151 in Illinois, and 18 in Iowa and Indiana) that we were able 


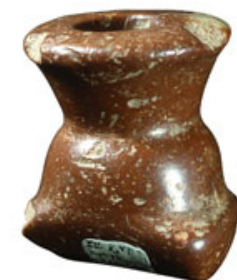

a

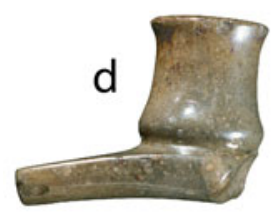

e

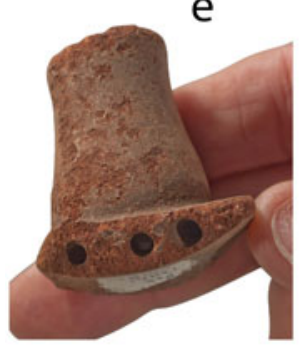

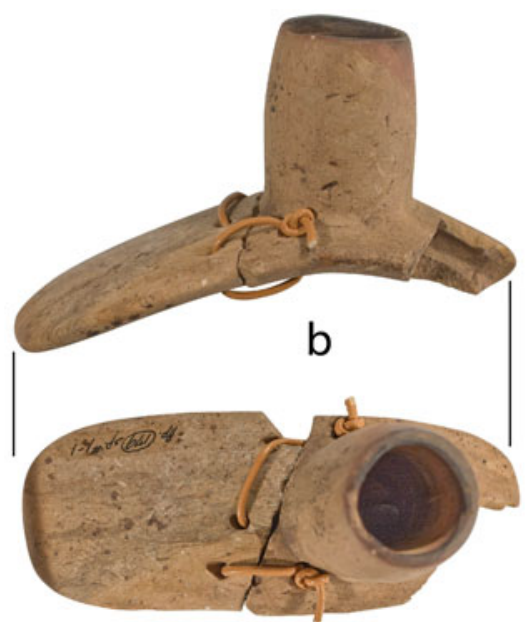
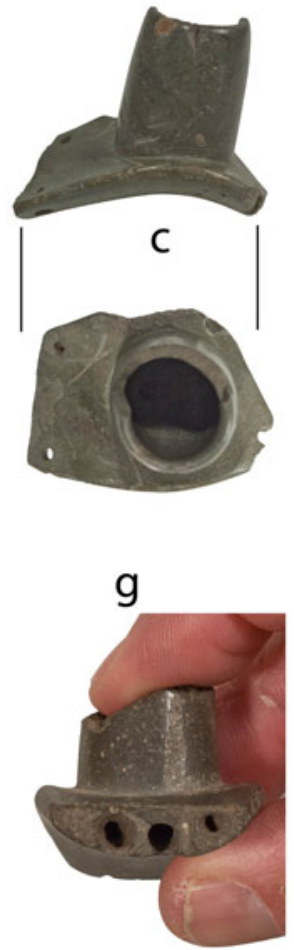

Figure 6. Examples of damaged and repaired platform pipes from Illinois Middle Woodland habitation sites: (a) Hall Creek site surface (Knox Co.) pipe, with both front and rear platforms broken off and ground smooth at the breaks for continued use; (b) Apple Creek site (Greene Co.), Feature 179 and surface fragments drilled and re-laced together to restore rear platform; front platform also partly broken away, shortened, and ground smooth; (c) Simpson \#1 site surface (Randolph Co.), with both front and rear platforms broken away; front and rear platforms drilled and re-laced together; rear platform lacing failed, and it was then shortened and ground smooth; (d) Meredosia site (Morgan Co.), disturbed surface, with rear platform of pipe broken off and ground smooth at the break for continued use; (e) Peisker site excavations (TS 934-01; Calhoun Co.), with front platform break drilled and pegged around stem hole to reattach platform; (f) Crane site (Greene Co.) surface, with front platform partly broken away and reground smooth; (g) Swartz site excavations (TS 6; Pike Co.), with front platform broken away and drilled and pegged around stem hole to reattach platform (not to scale; photographs courtesy of Kenneth Farnsworth). (Color online)

Table 1. Stone Platform-Pipe Distribution Total in the Illinois Study Area.

\begin{tabular}{lcccccccc}
\hline & & & & & Total Pipes, & & \\
& Effigy & Plain Bowl & $\begin{array}{c}\text { Total Intact } \\
\text { Pipes }\end{array}$ & Fragments & Preforms & $\begin{array}{c}\text { Intact Pipes } \\
\text { Preforms }\end{array}$ & $\begin{array}{c}\text { Sites } \\
\text { per Site }\end{array}$ \\
\hline Habitations & $17(15 \%)$ & $93(85 \%)$ & 110 & 96 & 20 & 226 & 96 & 1.14 \\
Mortuary & $49(25 \%)$ & $146(75 \%)$ & 195 & 0 & 2 & 197 & 104 & 1.88 \\
Total Examined & $66(22 \%)$ & $239(78 \%)$ & 305 & 96 & 22 & 423 & 200 & 1.52 \\
\hline
\end{tabular}

to access for Portable Infrared Mineral Analyzer (PIMA) analysis (Table 2). This sample of approximately $40 \%$ of pipes in current collections and those known only from historical documents, pipe fragments, and preforms from the Illinois region included 104 plain platform pipes, 38 effigies, 3 preforms, and 24 fragments; 155 of the 169 analyzed pipes could be identified 
as to geological source. This analysis indicated that $55 \%(n=86)$ of the pipes with an identified raw material are made of Sterling pipestone, whereas $34 \%(n=52)$ were made from a variety of local limestones, claystones, dolomites, and shales. We have identified, however, examples of imported exotic materials used to make platform pipes found in Illinois. Catlinite was predominant among imports although it was still only represented by seven pipes (5\%). Other rare materials are represented in $6 \%(n=10)$ of the pipes, and they include serpentine, Wyandotte Cave aragonite, black chlorite, and steatite.

Clearly, Illinois Havana Hopewell groups employed limited effort in seeking out and acquiring distant nonlocal pipestones. There seems to have been no special preference for Sterling or exotic pipestones in the crafting of effigy pipes. Of the 36 effigies pipes for which a geological source could be determined, $42 \%$ were made of Sterling, 39\% were of one of the local sedimentary stones (limestone, shale, siltstone, etc.), $5 \%$ were imported catlinite, and $14 \%$ were crafted from other exotic material (Table 2). The use of materials for effigy pipes somewhat mirrors the proportions of those pipestones used for the manufacture of pipes as a whole. Within the study area, effigies are $22 \%$ of the total assemblage, but they are slightly more common in individual mortuary contexts (15\% of pipes in habitation deposits and $25 \%$ of pipes as grave inclusions; Table 1).

Sterling pipestone objects are not equally distributed across the 108 counties that we include in our Illinois region: Sterling pipestone is present in 26 Illinois, three Iowa, and one Indiana counties (Table 3). As we might expect, they

Table 2. Illinois Region Platform Pipes Raw Material Sample Identified by PIMA Analysis.

\begin{tabular}{lcc}
\hline Raw Material & Effigy Forms & Total Pipes \\
\hline Sterling & $15(42 \%)$ & $86(55 \%)$ \\
Local Sedimentary & $14(39 \%)$ & $52(34 \%)$ \\
Catlinite & $2(5 \%)$ & $7(5 \%)$ \\
Exotics & $5(14 \%)$ & $10(6 \%)$ \\
No ID (8\% of total) & $2^{\mathrm{a}}$ & $14^{\mathrm{a}}$ \\
Total $^{\mathrm{a}}$ & $38(100 \%)$ & $155(100 \%)$ \\
\hline
\end{tabular}

${ }^{\text {a }}$ Totals do not include pipes whose geological material was unidentifiable, usually because the mineralogical signature had been destroyed by heating. are found in the greatest numbers closest to the source quarries, with one-third of all recorded Sterling pipestone pipes found at lower Rock River-Sterling-Albany-Gast Farms-Toolesboro locations (nine counties), and a little over onehalf of them in the adjacent central and lower Illinois River and adjacent Mississippi River valley sites (11 counties; Figure 1; Table 3 ). Three localized county clusters of Sterling pipestone pipes are known within these two regions: Whiteside (9), Fulton (12), and Pike (10). Sites in these three counties account for $36 \%$ of Sterling pipestone pipes in Havana Hopewell. Outside of these areas (with the exception of Tremper Mound, Ohio), the only other cluster of Sterling pipestone pipes (nine) is from the locality (six counties) at the lower WabashOhio River confluence region. The almost total lack of Sterling pipestone (two specimens) at the major Crab Orchard Tradition Twenhafel site in Jackson County is worth noting.

\section{Intramound Contexts of Illinois Platform Pipes}

In the heyday of Sterling pipestone use in Illinois Havana Hopewell, the number and sizes of documented Middle Woodland habitation sites and mound groups suggest that by far the greatest Middle Woodland population densities were concentrated in the central and lower Illinois Valley drainage. The nine adjacent counties in the Illinois and Mississippi River confluence area of westcentral Illinois are the location of fully half of the 185 habitation and mortuary sites with pipes we have identified within Illinois (Figure 1).

We have identified 310 intact pipes from 42 Illinois counties, 29 from four Iowa counties, and two from a single Indiana county (Table 3), and we are confident of their provenience to the county level. Of these counties, 12 account for approximately $70 \%$ of the recovered pipes, with specific county pipe totals ranging from 11 to 45. As was the case of the Sterling pipestone distribution, the highest number of pipes occurs in a few restricted localities such as Pike (45), Fulton (23), Calhoun (42), and the Iowa cluster of Scott and Louisa (29) counties. Even more impressive is the clustering of $55 \%$ of all Havana Hopewell pipes in the dozen or so counties of the central and lower Illinois River valley and the heavy density of pipes in the Quad City 
Table 3. Distribution of 341 Hopewell Pipes by County, State, and Sterling Pipestone.

\begin{tabular}{|c|c|c|c|c|}
\hline State & County & $\begin{array}{c}\text { Sterling } \\
\text { Pipestone } \\
\text { (\#) }\end{array}$ & $\begin{array}{c}\text { Total } \\
\text { Hopewell } \\
\text { Pipes (\#) }\end{array}$ & $\begin{array}{c}\text { County } \\
\text { Percent of } \\
\text { Total } \\
\text { Pipes }^{\mathrm{a}}\end{array}$ \\
\hline \multirow[t]{45}{*}{ IL } & Adams & & 12 & $4 \%$ \\
\hline & Bond & & 1 & \\
\hline & Brown & & 4 & \\
\hline & Calhoun & 3 & 42 & $12 \%$ \\
\hline & Carroll & 1 & 2 & \\
\hline & Clay & 1 & 3 & \\
\hline & Clinton & & 1 & \\
\hline & Franklin & & 1 & \\
\hline & Fulton & 12 & 23 & $7 \%$ \\
\hline & Greene & 5 & 15 & $4 \%$ \\
\hline & Hamilton & 1 & & \\
\hline & Hancock & & 3 & \\
\hline & Hardin & 2 & 3 & \\
\hline & Henderson & 1 & 1 & \\
\hline & Henry & 3 & 5 & \\
\hline & Jackson & 2 & 8 & \\
\hline & Jersey & 1 & 11 & $3 \%$ \\
\hline & Jo Daviess & 3 & & \\
\hline & Knox & 2 & 7 & \\
\hline & LaSalle & 1 & 6 & \\
\hline & Logan & 2 & 4 & \\
\hline & Macoupin & & 2 & \\
\hline & Madison & 2 & 5 & \\
\hline & Mason & & 1 & \\
\hline & Mercer & 1 & 3 & \\
\hline & Monroe & & 2 & \\
\hline & Morgan & 2 & 5 & \\
\hline & Ogle & & 1 & \\
\hline & Peoria & & 5 & \\
\hline & Piatt & 1 & & \\
\hline & Pike & 10 & 45 & $13 \%$ \\
\hline & Putnam & 1 & & \\
\hline & Randolph & & 5 & \\
\hline & Rock Island & & 13 & $4 \%$ \\
\hline & Saline & 1 & 1 & \\
\hline & Schuyler & 2 & 16 & $5 \%$ \\
\hline & Scott & 3 & 13 & $4 \%$ \\
\hline & St. Clair & & 3 & \\
\hline & Tazewell & 2 & 5 & \\
\hline & Wabash & & 2 & \\
\hline & White & 2 & 9 & \\
\hline & Whiteside & 9 & 12 & $4 \%$ \\
\hline & Will & & 3 & \\
\hline & Williamson & & 4 & \\
\hline & $\begin{array}{l}\text { Illinois } \\
\text { Totals }\end{array}$ & 73 & 310 & $60 \%$ \\
\hline \multirow[t]{5}{*}{ IA } & Des Moines & & 1 & \\
\hline & Louisa & 3 & 17 & $5 \%$ \\
\hline & Muscatine & 1 & 1 & \\
\hline & Scott & 7 & 10 & $3 \%$ \\
\hline & $\begin{array}{l}\text { Iowa } \\
\text { Totals }\end{array}$ & & 29 & $8 \%$ \\
\hline
\end{tabular}

Table 3. Continued.

\begin{tabular}{llccc}
\hline State & County & $\begin{array}{c}\text { Sterling } \\
\text { Pipestone } \\
(\#)\end{array}$ & $\begin{array}{c}\text { Total } \\
\text { Hopewell } \\
\text { Pipes (\#) }\end{array}$ & $\begin{array}{c}\text { County } \\
\text { Percent of } \\
\text { Total } \\
\text { Pipes }^{\mathrm{a}}\end{array}$ \\
\hline IN & $\begin{array}{l}\text { Posey } \\
\text { Indiana } \\
\text { Totals }\end{array}$ & 2 & 2 & \\
& TOTAL & $\mathbf{2}$ & $\mathbf{2}$ & \\
\hline
\end{tabular}

${ }^{a}$ Percentages given only for counties with high numbers of pipes; percentage of total pipes is shown, demonstrating that 12 counties account for $68 \%$ of recovered pipes.

locality (14\%). Once we move outside of these high-density clusters, pipes drop off quickly to just a few per county (Figure 1; Table 3).

These high-density clusters of Hopewell mounds and habitations in northwestern and west-central Illinois provide important evidence on the contexts of pipes in Havana Tradition mortuary ritual. In general, they reveal a pattern of one to three platform pipes in graves containing the remains of individuals of mixed ages and sexes. Pipes are rare grave inclusions, and they are not the "norm" for most burials at regional mortuary sites. A select sample from five welldocumented avocational and professional excavations of Havana Hopewellian mound groups located along the Illinois and Mississippi River valleys in west-central Illinois demonstrates this (Supplemental Text 3). It includes two floodplain mound groups and three bluff crest mound groups yielding 533 burials and 24 pipes. At these five mortuary sites, the pipes were found in individual graves or log-tomb structures associated with adult burials. It should be noted that Havana Hopewell burial programs were often performed in stages during which the movement of individuals from central tombs to peripheral locations occurred (Brown 1981). Apparently, therefore, these locations do not represent two discrete populations.

This pattern can be further illustrated by examining burials recorded by archaeologists at Illinois-area mound groups with major Havana Hopewellian components (Supplemental Text 4). The data include 987 Middle Woodland individual burials excavated at 11 floodplain and blufftop mound groups in the lower Illinois Valley and adjacent Mississippi Valley region of 
west-central Illinois, where 29 platform pipes, including nine effigy pipes and 20 plain-bowl pipes, were found. Platform pipes were buried as apparent personal possessions with only 20 of 987 individuals_-just $2 \%$ of the Hopewellian individuals in the sample.

\section{Discussion}

Illinois platform pipes are found across Havana Hopewell Tradition sites largely as intact mortuary objects associated with specific persons or events, or as discarded broken pipes and fragments in habitation midden debris. Pipes are never found collected en masse and smashed in large mortuary deposits or other contexts that would suggest a large-scale communal ritual deposition (e.g., as in some Ohio instances).

As we observe above, only 29 platform pipes were recovered from nearly 1,000 burials in 11 floodplain and blufftop mound sites in westcentral Illinois. The largest single grouping of pipes consisted of four, with one child/adult burial. In only $2 \%$ of excavated Illinois Middle Woodland burials were pipes present as apparent personal possessions-or, perhaps, as symbols of affiliation or accomplishment. In only two instances (both involving effigy pipes) were these burials of children. It is notable thathere, at the source of Sterling pipestone-platform pipes were seldom possessed by Havana Hopewell Tradition individuals, suggesting that their possession may have been closely regulated by social and religious strictures that served to constrain their distribution and possession to specific individuals as markers of prestige, status, religious, or group membership. Examining the patterns in Havana Hopewell platform-pipe manufacturing and raw material use, maintenance and curation, spatial distribution, disposition, and context variously highlights, contradicts, corroborates, or complements some of the patterns of mortuary practices and the distribution of powerful objects that earlier Hopewell researchers have observed.

In the Illinois area, imported exotic and catlinite pipestones/pipes are seldom encountered (11\% total; Table 2). Havana Hopewell Tradition people focused equally on local Sterling pipestone and local varieties of siltstone, limestones, and claystones. It is striking that no pipes made of Feurt Hill Ohio pipestone ${ }^{4}$, and only a few examples of catlinite (5\%), have been recovered in Illinois Havana Hopewell contexts, despite early Ohio Hopewell people receiving large numbers of Sterling pipestone pipes and red Minnesota pipestone likely passing though or by Illinois on its way to Ohio (Emerson et al. 2005, 2013). Obviously, terms such as "exotic" and "nonlocal" are culturally relative. In the case of early Hopewell Ohio societies (e.g., Tremper Mound), especially for pipes, the concept of "exotic" may be linked to distance, so that pipestones, obsidian, cherts, animal parts, and metals from hundreds of kilometers away had significant value-local, easily available Feurt Hill pipestone or Portsmouth claystones did not (Emerson et al. 2013; Seeman 2020; Seeman et al. 2019). Interestingly, this valuation changed with time so that the somewhat later ceremonial disposition of platform pipes in Mound City was dominated by those made from local pipestones. Conversely, Illinois Havana Hopewell Tradition populations, when considering pipes, apparently did not perceive the distance of origin as an object's primary value. Therefore, relatively "local" Sterling or sedimentary deposits held more meaning than carveable stone that was geographically more distant, or regional sociopolitical relations were such that foreign pipestones were unobtainable (e.g., Emerson and Hughes 2000:Note 4; Seeman 1995).

It is intriguing that the largest and most heavily constructed Hopewellian site complexes in our Illinois study area (Toolesboro-Albany and the lower Illinois River valley)-with their impressive and sprawling built environments of earthworks and associated burial mounds-are located at the far northwestern riverine edge of the Illinois Havana Hopewell country, at what appear to have been the margins of this western Hopewellian world. There are dramatic increases in our documented pipe densities in the Quad Cities area, including the Albany and Gast FarmToolesboro site complexes in northwestern Illinois, eastern Iowa on the western edge of the Sterling pipestone source locale itself, and the lower Illinois River valley, just to the south of the Sterling deposits. It should also be noted that these locales are on the doorstep of areas to 
the west that are known to have provided items such as obsidian, catlinite, grizzly-bear teeth, and Knife River flint.

What is challenging is determining how these various ceremonial/ritual locales interact and reflect the vast majority of Illinois Havana Hopewell Tradition populations in the interior of the state. Based on the available evidence, Havana populations in the Illinois River corridor and American Bottom represent seemingly localized political-kin groups whose interaction was primarily focused on the local ceremonial-ritualreligious-political interactions as described by Douglas Charles (1992, 1995, 2010, 2012; Ruby et al. 2005; but see Byers [2015:286223] and Martin [2005:288-308] for a differing perspective). Charles envisions the interactions that might link residentially integrated, territorially based communities as symbolic communities that can be created through networks of shared ideology, sodalities, kinship, trade, or other variables. The elements that create such a community are likely to be fluid, intermeshed, entangled, and, perhaps, sporadic and transitory.

The archaeological indications of such symbolic communities might be reflected in the movement of material symbolic objects along the resultant social, political, and religious networks. The evidence certainly indicates the contiguous distribution of linear, territorially based, Hopewell-era communities in the Illinois and adjacent Mississippi River valleys that would encourage the development of shared ideological beliefs in terms of mortuary practices and their materialization. The distribution of platform pipes within the valleys seems to indicate that they served as markers of a shared communal ideology_perhaps captured in their distinctive styles and widespread use of the equally distinctive Sterling pipestone. Pipes appear to be powerful artifacts associated with individual prominence and affiliation. How that prominence was attained is unclear-whether through religious, political, kinship, or social achievement. However, their distribution also suggests, given the rare burial of pipes with children, that such objects and their associated power could be transferred in certain unknown circumstances. Regardless, it is apparent that access to stone platform pipes was restricted to a limited portion of the population.
There is a rich anthropological literature, much of it tied to North American Natives, that documents human purpose and agency in a ritual, religious, social, economic, and cultural context that can be brought into play to model Hopewell behavior. The crux of the problem is explaining the materialization, emergence, homogeneity, variance, and movement of Havana Hopewell symbols. Carr's (2005a:579-623) encyclopedic compendium of ethnographically known mechanisms for movement of objects includes vision and power quests; pilgrimages to places of power or ceremonial centers; travels by healers, patients, or seekers to learn ceremonial rites or gain esoteric knowledge; long-distance trade; spirit adoptions; interregional marriages; elite exchange of valuables; or elite-mediated transference of religious cults and practices.

Although the specific mechanisms generating the acquisition and deployment of platform pipes within the contemporaneous Hopewell-era societies may be unclear, it does seem that how the exotic (and local) platform pipes were employed by the Ohio Hopewell societies had some significantly different sociopolitical aspects than those proposed for Havana Tradition society. This is most dramatically illustrated in Ohio by the final dispositions of some pipes as part of spectacular, communal destructive events performed as part of a complex sequence of mound ceremonialism that is unmatched in the Havana Tradition. Carr interprets (2008a:233-236, 278280; 2008b:308; also see Byers 2015:164-170) such pipes as tied to shamanistic sodalities, and their deposition as representing the termination of a long-term ceremonial cycle. He proposes that numerous sodalities, clans, and ceremonial societies that were complementary in their social roles and comparable in prestige-as well as prominent individuals-interacted to enable the existence, promotion, and continuance of Ohio Hopewell's elaborate and complex ceremonial and religious infrastructure. ${ }^{5}$

\section{Conclusion}

The contexts of platform pipes in Illinois Hopewell-era societies indicate that pipes were generally held as objects linked to the personal power or status of the few individuals who 
possessed them, given the widespread sacred implications of tobacco as well as its potency in ceremonial, spiritual, and political activities in Native societies. Although Sterling pipestone use becomes more common for Havana Hopewell Tradition pipes, there seems to be no inherently powerful or restrictive association with the stone itself. This attitude may also be reflected in the general absence of foreign exotic pipestone raw materials, such as Feurt Hill pipestone or catlinite.

As the evidence from the artifact documentation and sourcing portion of this study converge, strong patterns of Havana Tradition pipe deposition and raw-material use have become apparent. These include the following:

- The classic Hopewell-era pipes discussed here are part of a lengthy stylistic pipe development that can be traced from Late Archaic / Early Woodland through the early Late Woodland periods. The Hopewellian platform-pipe style in the Eastern Woodlands was likely first developed in the Havana region. Although Sterling pipestone was used in the lower Rock River area of Illinois over the long term from the Middle Archaic to the historic period, the geographic expansion of its use only occurred during the Middle Woodland period.

- Illinois Sterling pipestone deposits, not Ohio Feurt Hill pipestone quarries, provided a major raw material source for Havana Hopewell Tradition platform pipes. More than 55\% of the analyzed Havana pipes and $40 \%$ of all analyzed Havana effigy pipes from the Illinois region were made of Sterling pipestone.

- The identification of multiple Illinois locations where pipestone was crafted into pipes for local, regional, and interregional distribution suggests their crafting was not ritually or socially restricted; however, the stylistic uniformity of some high-quality (effigy) pipes in both Illinois and the Ohio Tremper Mound deposit suggest that only a few people crafted these examples.

- It provides overwhelming evidence for a primarily western Illinois-centric manufacture, distribution, use, and long-term curation of platform pipes made from Sterling and other local pipestones in Havana Hopewell Tradition times, with about $90 \%$ of assayed pipes and
$80 \%$ of all assayed effigy pipes having been made of local stones (Sterling pipestone and other local sedimentary stones).

- Platform pipes made of Sterling pipestone were, through a currently unknown mechanism, moved to Ohio in early Hopewell times, where they were valued by the local societies and where they dominated smoking-pipe use. Pipestone exchange was not reciprocal, and platform pipes made of Ohio Feurt Hill pipestone were not moved from there to the Illinois Havana area.

- Havana Hopewell people placed little value on obtaining and utilizing nonlocal, distant pipestones for pipe manufacture, in contrast to the procurement and use of other distant raw materials to make ceremonial and social items.

- Finished pipes from Illinois habitation contexts show-by their wear, repair, and modification when damaged - that they were treasured.

- Platform pipes in Illinois were deposited equally in habitation and mortuary contexts.

- An examination of pipe disposal practices at Illinois-area habitation sites and mortuary earthworks demonstrates that pipes are rare as burial objects, limited to the inclusion of pipes with a small number of individuals $(2 \%)$. They were therefore apparently personal possessions or symbols of affiliation or accomplishment, and they never were decommissioned in massive ceremonial deposits that marked multicommunity ceremonies such as those in the early Ohio Scioto Tradition.

- It is not unreasonable to assume-given the low numbers of pipes in Illinois, their likely ritual importance, and the tendency of these pipes to accompany some individuals in death-that they may have been linked in some instances to the widespread practices of tobacco ritualism but not common household rituals. These basic facts also point to the practices of such spiritualists as individualistic rather than those performed as members of a sodality, such as inferred for Scioto Hopewell societies.

- Individuals buried with platform pipes in the Illinois Havana area were of mixed ages and sexes.

- All told, archaeological evidence points to the conclusion that interpreting the Havana Tradition practices predominantly within the perspective of a Hopewellian Ohio-centric 
interaction sphere has hindered understanding of the tradition's unique local social, religious, and political development, which occurs quite outside an Ohio sphere of influence.

Ultimately, understanding the nature of what it means to be Hopewell in the Eastern Woodlands will only be achieved by dissecting and understanding the social, economic, religious, and political parameters of local societies (see Carr 2005a; Henry and Miller 2020; Wright 2020). We do not mean to imply that exotics such as marine shell, obsidian, chert, copper, mica, galena, and other high-value objects are not present in Illinois Havana Hopewell.

Such exotics must be understood within the local context. ${ }^{6}$ In some cases, for example, Havana Tradition's geographical proximity to the sources of galena (Seeman 1979; Walthall 1981) and catlinite, or on the pathway for obsidian, may have provided its peoples important leverage in accessing other highly regarded materials. It is apparent that the overemphasis on the occasional movement of rare or exotic objects can obscure the important questions of the internal development of local Middle Woodland societies. In Illinois, studying these questions has been well underway for a half-century through archaeological research that has broadly sought to understand the integration of local subsistence, settlement, and mortuary practices (e.g., research by David Asch, Nancy Asch, Douglas Charles, Jane Buikstra, Andrew Fortier, and others). The continuance of such deconstruction studies are an important part of revealing the variable impact of the Hopewellian phenomena in the eastern United States.

Acknowledgments. This research been ongoing since the mid-1990s and has benefited from the assistance and cooperation of many colleagues. Although they cannot all be individually acknowledged, we gratefully thank them for their help. Without the long-term commitment of the Illinois State Museum, Dickson Mounds Museum, Illinois State Archaeological Survey, Putnam Museum, Milwaukee Public Museum, Gilcrease Museum, Center for American Archeology, the Church of Jesus Christ of Latter-Day Saints, British Museum, Upper Mississippi Valley Archaeological Research Foundation, Wisconsin Historical Society, Southern Illinois University Carbondale Center for Archaeological Investigations, University of Michigan Museum of Anthropology, Ohio History Collection, and the Chicago Field
Museum of Natural History and their staff to the preservation of these collections, and the generous assistance of many avocational archaeologists and artifact collectors who shared their historically significant materials, this study would not have been possible. This research was invigorated by discussions, information, and observations from Martin Byers, Christopher Carr, William Green, Shannon Fie, Andrew Fortier, N'omi Greber, Martha Potter Otto, Mark Seeman, and John Walthall. We are grateful for the observations of several anonymous reviewers, as well as for the critiques and advice of Christopher Carr, who assisted us in both interpreting the Ohio collections and clarifying our interregional arguments for Hopewellian interaction. Editor Lynn Gamble and editorial assistant Alicia Gorman provided essential feedback, insights, and assistance in bringing this manuscript to publication. We want to acknowledge the long-term input of our colleague Sarah Wisseman, who has been a central part of our two decades of pipestone research. PIMA data was collected with the assistance of Sarah Wisseman, Kjersti Emerson, and Mary Hynes. Figures 1, 2, and 4-6 were produced by Kjersti Emerson and Thomas Emerson with photographs by Kenneth Farnsworth. This study is based on work partially supported by the National Science Foundation under grant numbers 9971179 and 0203010 . We also acknowledge logistical and some financial support for this scientific research by the Illinois State Archaeological Survey and the Illinois State Geological Survey. Any opinions, findings, and conclusions or recommendations expressed in this material are those of the authors and do not necessarily reflect the views of the National Science Foundation. The authors declare no conflicts of interest.

Data Availability Statement. The PIMA analysis data records are available by request from T. Emerson, ISAS. Pipe documentation records are available by request from K. Farnsworth, ISAS

Supplemental Materials. For supplemental material accompanying this article, visit https://doi.org/10.1017/aaq.2021.34.

Supplemental Text 1. Establishing a Context for Examining Illinois Hopewell-Era Legacy Collections for Evidence of Pipestone Use and Exchange.

Supplemental Text 2. Sourcing Pipestone.

Supplemental Text 3. Distribution of Pipes in Mortuary Context 1.

Supplemental Text 4. Distribution of Pipes in Mortuary Context 2.

\section{Notes}

1. Martin Byers (2015:27-50) has laid out an intriguing argument to reclaim and re-enliven the conceptual foundations of Caldwell's HIS by envisioning it as representing interconnected world renewal and mourning ceremonies integrated through communally heterarchically organized clans and sodalities.

2. It should be noted that the 72 Sterling pipestone pipes and pipes fragments recovered from the Ohio Tremper Mound deposit (Emerson et al. 2013:Table 2) almost equal the total number of similar Sterling pipestone specimens for the entire Illinois region recorded in our available sample $(n=86)$. 
3. This analysis focuses on the mineralogy and distribution of Havana Hopewell platform pipes in Illinois and its riverine borderlands. Locating, photographing, and mineralogically analyzing archaeologically recovered Illinois-area pipes and pipe fragments - and tracking down and documenting context for Illinois-area antiquarian pipe discoveries dating back as far as the 1840 s- has been a time-consuming process going back at least four decades. During the process of locating specimens, Farnsworth discovered the added distraction of weeding out more than 1,500 increasingly sophisticated modern pipe forgeries-including many made by artistically skilled carvers with access to the Ohio pipestone quarries who employ ingenious raw-material coloration methods, heat-based aging techniques, and solution-chemistrybased surface incrustation skills. Although fascinating and educational, these forgeries have hindered this study. Such skilled forgeries present a significant challenge to researchers.

4. Farnsworth and colleagues (2016:333) mention a possible single example of a Feurt Hill pipestone effigy bird pipe from an Illinois site. This cream-colored, red-speckled owl effigy platform pipe is from an uncontrolled excavation of a blufftop mound (Oscar Hood Mound) in Fulton County, Illinois. This tentative identification was revisited by Dr. Randall Hughes in 2020. Since then, he has carried out additional analysis and examined a wider range of pipestone samples from the involved quarries. Although the Oscar Hood pipe spectra were still somewhat ambiguous, he determined the best fit was with the Sterling pipestone source. It is clear that the Tremper Mound Ohio recipients of Illinois pipes preferentially sought Illinois Sterling pipe effigy forms (Emerson et al. 2013:Table 2) but apparently did not reciprocate with pipes of Ohio pipestones. This supports Seeman's (2020:330 331 ) observation that Ohio Hopewell practices focus primarily on procurement rather than on exchange.

5. Evidence of such systematic corporate practices is missing among the Illinois Havana Hopewell societies, at least in regard to pipe dispositions. This does not imply, however, that Havana Hopewell pipes have no association with otherworldly powers. The association of Hopewell pipes (especially the effigy styles) with ritual and spiritual practices has been proposed by Eastern Woodland scholars (e.g., Brown 1997, 2006; Romain 2009). The evidence for tobacco shamanism in the region has been discussed in detail elsewhere (Blanton 2015; Emerson 2003:135-138, 143-144) and its practice by some spiritualists among the Havana Hopewell groups seems possible. Such ritualists, however, are manifested as individual practitioners, and consequently, their roles in the local social infrastructures are socially and politically very different from those in organized sodalities referenced in Carr's (2008a) discussions of Scioto Hopewell shamanistic groups. Although spiritual power may be imbued in some pipes, it is unlikely that it can serve as an explanation for the presence and uses of all Havana Hopewell pipes.

6. Although pipes are confined to primarily single occurrences, it is hard to ignore the communal/ceremonial implications of the deposition of masses of gray chert ovate disks at Neteler or Baehr mounds in the Illinois River valley (e.g., Daniels and McElrath 2010; Morrow 1992).

\section{References Cited}

Abrams, Elliot M.

2009 Hopewell Archaeology: A View from the Northern Woodlands. Journal of Archaeological Research 17:169-204.
Alex, Lynn M., William Green, and Robin M. Lillie

2019 Toolesboro: A Havana-Hopewell Mound Group in Southeastern Iowa. Journal of the Iowa Archaeological Society 66:1-79.

Applegate, Darlene

2005 Woodland Taxonomy in the Middle Ohio Valley: A Historical Overview. In Woodland Period Systematics in the Middle Ohio Valley, edited by Darlene Applegate and Robert Mainfort Jr., pp. 1-18. University Alabama Press, Tuscaloosa.

Asch, David L., Kenneth B. Farnsworth, and Nancy B. Asch 1979 Woodland Subsistence and Settlement in West Central Illinois. In Hopewell Archaeology: The Chillicothe Conference, edited by David S. Brose and N'omi Greber, pp. 80-85. Kent State University Press, Kent, Ohio.

Blanton, Dennis B

2015 Mississippian Smoking Ritual in the Southern Appalachian Region. University of Tennessee Press, Knoxville.

Bluhm, Elaine, Margaret Hoffman, and Michael Hoffman

1961 Preliminary Report on the Archaeological Survey of the Rock River Valley. On file, Illinois State Archaeological Survey, Urbana.

Bluhm Herold, Elaine

1971 The Indian Mounds at Albany, Illinois. Davenport Museum Anthropological Papers 1. Davenport Museum, Davenport, Iowa.

Brown, James A.

1981 The Search for Rank in Prehistoric Burials. In The Archaeology of Death, edited by Robert Chapman, Ian Kinnes, and Klavs Randsborg, pp. 25-37. Cambridge University Press, Cambridge.

1997 The Archaeology of Ancient Religion in the Eastern Woodlands. Annual Review of Anthropology 26:465485 .

2006 The Shamanic Element in Hopewellian Period Ritual. In Recreating Hopewell: New Perspective on Middle Woodland in Eastern North America, edited by Douglas K. Charles and Jane E. Buikstra, pp. 475488. University of Florida Press, Gainesville.

Byers, A. Martin

2015 Reclaiming the Hopewellian Ceremonial Sphere: $200 B C$ to $A D$ 500. University of Oklahoma Press, Norman.

Caldwell, Joseph R.

1964 Interaction Spheres in Prehistory. In Hopewellian Studies, edited by Joseph R. Caldwell and Robert L. Hall, pp. 133-143. Scientific Papers Vol. 12. Illinois State Museum, Springfield.

Carr, Christopher

2005a Rethinking Interregional Hopewellian Interaction. In Gathering Hopewell: Society, Ritual, and Ritual Interaction, edited by Christopher Carr and D. Troy Case, pp. 575-623. Kluwer Academic/Plenum Publishers, New York.

2005b Historical Insight into the Direction and Limitations of Recent Research on Hopewell. In Gathering Hopewell: Society, Ritual, and Ritual Interaction, edited by Christopher Carr and D. Troy Case, pp. 51-70. Kluwer Academic/Plenum Publishers, New York.

2008a Social and Ritual Organization. In The Scioto Hopewell and Their Neighbors: Bioarchaeological Documentation and Cultural Understanding, edited by D. Troy Case and Christopher Carr, pp. 151-288. Springer, New York. 
2008b World View and the Dynamics of Change: The Beginning and the End of Scioto Hopewell Culture and Lifeways. In The Scioto Hopewell and Their Neighbors: Bioarchaeological Documentation and Cultural Understanding, edited by D. Troy Case and Christopher Carr, pp. 289-328. Springer, New York.

Carr, Christopher, and D. Troy Case

2005 The Gathering of Hopewell. In Gathering Hopewell: Society, Ritual, and Ritual Interaction, edited by Christopher Carr and D. Troy Case, pp. 19-50. Kluwer Academic/Plenum Publishers, New York.

Carr, Christopher, and D. Troy Case (editors)

2005 Gathering Hopewell: Society, Ritual, and Ritual Interaction. Kluwer Academic/Plenum Publishers, New York.

Case, D. Troy, and Christopher Carr (editors)

2008 The Scioto Hopewell and Their Neighbors: Bioarchaeological Documentation and Cultural Understanding. Springer, New York.

Charles, Douglas K.

1992 Woodland Demographic and Social Dynamics: Mortuary Sites in the American Midwest: Analysis of a Burial Mound Survey. World Archaeology 24:175197.

1995 Diachronic Regional Social Dynamics: Mortuary Sites in the Illinois River Valley/American Bottom Region. In Regional Approaches to Mortuary Analysis, edited by Lane A. Beck, pp. 77-99. Plenum, New York.

2010 Riverworld: Life and Meaning in the Illinois Valley, In Hopewell Settlement Patterns, Subsistence, and Symbolic Landscapes, edited by A. Martin Byers and Dee Anne Wymer, pp. 19-36. University Press of Florida, Gainesville.

2012 Origins of the Hopewell Phenomenon. In The Oxford Handbook of North American Archaeology, edited by Timothy R. Pauketat, pp. 471-482. Oxford University Press, New York.

Charles, Douglas K., and Jane E. Buikstra

2002 Siting, Sighting, and Citing the Dead. In The Place of Space and Death, edited by Helaine Silverman, pp. 13-25. Archaeological Papers 11. American Anthropological Association. Washington, DC.

Charles, Douglas K., and Jane E. Buikstra (editors)

2006 Recreating Hopewell: New Perspective on Middle Woodland in Eastern North America. University of Florida Press, Gainesville.

Charles, Douglas K., Steven R. Leigh, and Jane E. Buikstra (editors)

1988 The Archaic and Woodland Cemeteries at the Elizabeth Site in the Lower Illinois Valley. Center for American Archeology Research Series 7. Kampsville Archeological Center, Kampsville, Illinois.

Daniels, Stephanie L., and Dale L. McElrath

2010 A Reexamination of the Middle Woodland Chert Disks from Neteler Mound. Illinois Archaeology 22:747-759.

Deuel, Thorne

1952 The Hopewellian Community. In Hopewellian Communities in Illinois, edited by Thorne Deuel, pp. 249265. Scientific Papers 5. Illinois State Museum, Springfield.

Emerson, Thomas E.

2003 Materializing Cahokian Shamans. Southeastern Archaeology 22:135-154.

Emerson, Thomas E., Kenneth B. Farnsworth, Sarah U. Wisseman, and Randall E. Hughes
2013 The Allure of the Exotic: Reexamining the Use of Local and Distant Pipestone Quarries in Ohio Hopewell Pipe Caches. American Antiquity 78:48-67.

Emerson, Thomas E., and Randall E. Hughes

2000 Figurines, Flint Clay Sourcing, the Ozark Highlands, and Cahokian Acquisition. American Antiquity 65:79-101.

Emerson, Thomas E., Randall E. Hughes, Kenneth B. Farnsworth, and Sarah U. Wisseman

2021 Identifying Animate Stones and Sacred Landscapes: Twenty-Five Years of Native Pipestone-Quarries Research in the American Midcontinent. North American Archaeologist 42:177-204. DOI:10.1177/ 0197693120976136.

Emerson, Thomas E., Randall E. Hughes, Kenneth B. Farnsworth, Sarah U. Wisseman, and Mary Hynes

2005 Tremper Mound, Hopewell Catlinite, and PIMA Technology. Midcontinental Journal of Archaeology 30:189-216.

Everhard, Timothy D., and Bret J. Ruby

2020 Ritual Economy and the Organization of Scioto Hopewell Craft Production: Insights from the Outskirts of the Mound City Group. American Antiquity 85:279-304.

Farnsworth, Kenneth B.

2004 Hopewellian Studies in the Lower Illinois Valley, 1878-1928. In Early Hopewell Mound Explorations. The First Fifty Years in the Illinois River Valley, edited by Kenneth B. Farnsworth, pp. 4-98. Studies in Archaeology No. 3. Illinois Transportation Archaeological Research Program, University of Illinois, UrbanaChampaign.

2020 Appendix E: 1961-88 Archaeological Studies at the Sinnissippi and Propheter Sites in the Upper Rock River Valley, and Documentation of Late Prehistoric Exploitation of Local Sterling Pipestone Sources. In Investigations at the Propheter Site: A Multi-Component Settlement in Whiteside County, Illinois, edited by Andrew C. Fortier and Kenneth B. Farnsworth, pp. 229-264. Illinois State Archaeological Survey Technical Report No. 192. University of Illinois, Champaign.

Farnsworth, Kenneth B., and David L. Asch

1986 Early Woodland Chronology, Artifact Styles, and Settlement Distribution in the Lower Illinois Valley Region. In Early Woodland Archeology, edited by Kenneth B. Farnsworth and Thomas E. Emerson, pp. 326457. Kampsville Seminars in Archeology 2. Center for American Archeology, Kampsville, Illinois.

Farnsworth, Kenneth B., Thomas E. Berres, Randall E. Hughes, and Duane M. Moore

2004 1llinois Platform Pipes and Hopewellian Exchange: A Mineralogical Study of Archaeological Remains. In Aboriginal Ritual and Economy in the Eastern Woodlands: Essays in Memory of Howard Dalton Winters, edited by Anne-Marie Cantwell, Lawrence A. Conrad, and Jonathan E. Reyman, pp. 182-214. Scientific Papers Vol. 30. Illinois State Museum, Springfield.

Farnsworth, Kenneth B., Thomas E. Emerson, Randall E. Hughes, and Sarah Wisseman

2013 Hopewell Platform Pipes and Their Implications for Distinguishing Variation in Hopewell Mound Ceremonialism. Paper presented at the 57th Annual Midwest Archaeological Conference, Columbus, Ohio.

Farnsworth, Kenneth B., and Kristin M. Hedman

2020 Appendix D: Emergency Salvage Excavations at the Terminal Archaic Freeby Site Cemetery and Habitation 
Area, and the Earliest Documented Prehistoric Exploitation of the Sterling Pipestone Quarries. In Investigations at the Propheter Site: A Multi-Component Settlement in Whiteside County, Illinois, edited by Andrew C. Fortier and Kenneth B. Farnsworth, pp. 213-228. Illinois State Archaeological Survey Technical Report No. 192. University of Illinois, Champaign.

Farnsworth, Kenneth B., Mary Hynes, Randall E. Hughes, and Sarah U. Wisseman

2016 Final Long-Distance Trade of Late Woodland Sterling-Pipestone Platform Pipes in the Illinois Region. In "Cahokia and Beyond: Essays in Honor of Thomas E. Emerson," edited by John A. Walthall and David J. Nolan, special issue, Illinois Archaeology 28:331-364.

Fortier, Andrew C.

2006 The Land between Two Traditions: Middle Woodland Societies of the American Bottom. In Recreating Hopewell: New Perspective on Middle 1220 Woodland in Eastern North America, edited by Douglas K. Charles and Jane E. Buikstra, pp. 328-338. University of Florida Press, Gainesville.

Fortier, Andrew C., Thomas O. Maher, Joyce A. Williams, Michael C. Meinkoth, Kathryn E. Parker, and Lucretia Kelly

1989 The Holding Site (11-Ms-118): A Hopewell Community in the American Bottom. American Bottom Archaeology FAI-270 Site Reports Vol. 19. University of Illinois Press, Urbana.

Green, William

2018 High Resolution Mapping and Geophysical Assessment of the Gast Farm Site (13LA12), Southeast Iowa. Submitted to the National Geographic Society, Washington, DC, and the Center for Advanced Spatial Technologies, University of Arkansas, Fayetteville.

Griffin, James B.

1967 Eastern North American Archaeology: A Summary. Science 156:175-191.

Henry Edward R., and G. Logan Miller (editors)

2020 "Middle Woodland Ceremonial Situations in the North American Midcontinent." Special issue, Midcontinental Journal of Archaeology 45.

Henry, Edward R., and G. Logan Miller

2020 Toward a Situational Approach to Understanding Middle Woodland Societies in the American Midcontinent. Midcontinental Journal of Archaeology 45:187202.

Hughes, Randall E., Thomas E. Berres, Duane Moore, and Kenneth B. Farnsworth

1998 Revision of Hopewellian Trading Patterns in Midwestern North America Based on Mineralogical Testing. Geoarchaeology 13:709-729.

Koldehoff, Brad H., and Kenneth B. Farnsworth

2018 From Tubes to Platforms: Transformations in Early Smoking Pipes and Ancient Rituals. In Archaeology and Ancient Religion in the American Midcontinent, edited by Brad H. Koldehoff and Timothy R. Pauketat, pp. 29-80. University of Alabama Press, Tuscaloosa.

Martin, Andrew

2005 Agents in Inter-Action Bruno Latour and Agency. Journal of Archaeological Method and Theory $12: 283-311$

Mills, William C.

1916 Exploration of the Tremper Mound. Ohio Archeological and Historical Publications 25. Ohio Archeological and Historical Society, Columbus.
1922 Exploration of the Mound City Group. Ohio Archaeological and Historical Publications 31(4). Ohio Archeological and Historical Society, Columbus.

Morrow, Carol A.

1992 Observations on the Baehr Mounds Chert Disks: The American Museum of Natural History Collections. Illinois Archaeology 3:77-92.

Redmond, Brian G., Bret J. Ruby, and Jarrod Burks

2019 Encountering Hopewell in the Twenty-First Century, Ohio and Beyond: 1. Monuments and Ceremony. University of Akron Press, Akron, Ohio.

2020 Encountering Hopewell in the Twenty-First Century, Ohio and Beyond: 2. Settlements, Foodways, and Interaction. University of Akron Press, Akron, Ohio.

Romain, William F

2009 Shamans of the Lost World: A Cognitive Approach to the Prehistoric Religion of the Ohio Hopewell. AltaMira, Lanham, Maryland.

Ruby, Bret J., Christopher Carr, and Douglas K. Charles

2005 Community Organization in the Scioto, Mann, and Havana Hopewellian Regions: A Comparative Perspective. In Gathering Hopewell: Society, Ritual, and Ritual Interaction, edited by Christopher Carr and D. Troy Case, pp. 119-176. Kluwer Academic/Plenum Publishers, New York.

Seeman, Mark F.

1977 Stylistic Variation in Middle Woodland Pipe Styles: The Chronological Implications. Midcontinental Journal of Archaeology 2:47-66.

1979 The Hopewell Interaction Sphere: The Evidence for Interregional Trade and Structural Complexity. Prehistoric Research Series 5(2). Indiana Historical Society, Indianapolis.

1995 When Words Are Not Enough: Hopewell Interregionalism and the Use of Material Symbols at the GE Mound. In Native American Interactions: Multiscalar Analyses and Interpretation in the Eastern Woodlands, edited by Michael S. Nassaney and Kenneth Sassaman, pp. 122143. University of Tennessee Press, Knoxville.

2020 Twenty-First Century Hopewell. In Encountering Hopewell in the Twenty-First Century, Ohio and Beyond: 2. Settlements, Foodways, and Interaction, edited by Brian G. Redmond, Bret J. Ruby, and Jarrod Burks, pp. 313-342. University of Akron Press, Akron, Ohio.

Seeman, Mark F., Kevin C. Nolan, and Mark A. Hill

2019 Copper as an Essential and Exotic Hopewell Metal. Journal of Archaeological Science: Reports 24:10951101.

Silverberg, Robert

1968 Mound Builders of Ancient America: The Archaeology of a Myth. New York Graphic Society, New York.

Squier, Ephraim G., and Edwin H. Davis

1848 Ancient Monuments of the Mississippi Valley Comprising the Results to Original Surveys and Explorations. Contributions to Knowledge 1. Smithsonian Institution, Washington, DC.

Struever, Stuart

1964 The Hopewell Interaction Sphere in RiverineWestern Great Lakes Culture History. In Hopewell Studies, edited by Joseph R. Caldwell and Robert L. Hall, pp. 85-106. Scientific Papers 12. Illinois State Museum, Springfield.

1968 A Re-Examination of Hopewell in Eastern North America. PhD dissertation, Department of Anthropology, University of Chicago, Chicago. 
Struever, Stuart, and Gail L. Houart

1972 An Analysis of the Hopewell Interaction Sphere. In Social Exchange and Interaction, edited by Edwin N. Wilsen, pp. 47-80. Anthropological Papers No. 46. Museum of Anthropology, University of Michigan, Ann Arbor.

Walthall, John A.

1981 Galena and Aboriginal Trade in Eastern North America. Scientific Papers 17. Illinois State Museum, Springfield.

Whittaker, William E., and William Green

2010 Early and Middle Woodland Earthwork Enclosures in Iowa. North American Archaeologist 31:27-57.
Wisseman, Sarah U., Randall E. Hughes, Thomas E. Emerson, and Kenneth B. Farnsworth

2012 Refining the Identification of Native American Pipestone Quarries in the Midcontinental United States. Journal of Archaeological Science 39:2496-2505.

Wright, Alice P.

2020 Garden Creek: The Archaeology of Interaction in Middle Woodland Appalachia. University of Alabama Press, Tuscaloosa.

Submitted July 16, 2020; Revised January 22, 2021; Accepted January 30, 2021 